\title{
CHEMICAL CONTROL OF PHYTOPHTHORA WILT IN TOMATOES
}

\author{
CONTROLE QUÍMICO DA MURCHA DE FITÓFTORA NO TOMATEIRO
}

\author{
Laís Barbosa Prazeres MENDONÇA ${ }^{1}$; Lísias COELHO² Juliana STRACIERI $^{3}$; \\ João Batista FERREIRA JÚNIOR ${ }^{3}$; Nilvanira Donizete TEBALDI ${ }^{2}$ \\ 1. Eng. Agrônoma, M.Sc. Graduate student in Plant Pathology, Universidade Federal de Viçosa - UFV, Viçosa, MG, Brasil. \\ laisagro@gmail.com; 2. Professor, Doctor, Instituto de Ciências Agrárias, Universidade Federal de Uberlândia - UFU, Uberlândia, MG, \\ Brasil. lisias@iciag.ufu.br; 3. Graduate Student in Agronomia Produção Vegetal, Universidade Estadual Paulista "Júlio de Mesquita \\ Filho" Campus Jaboticabal, SP, Brasil.
}

\begin{abstract}
The most effective disease management method for yield reducing diseases affecting tomatoes is the use of fungicides. This study evaluated the efficacy of chemical control on three Phytophthora sp. isolates, pathogenic to tomatoes. The effect of fungicides on mycelial growth of Phytophthora sp. and on tomato wilt was evaluated in vitro and in vivo. Two tests were done in Petri plates, and one on seedlings, in completely randomized design as a $4 \times 3$ factorial, with 5 replications. In vitro tests were done in growth chamber, at $25^{\circ} \mathrm{C}$. The experimental unit consisted of a 5 -mm diameter fungal mycelial plug placed $30 \mathrm{~mm}$ away from a filter paper disk, of similar size, soaked in fungicide, over cornmeal agar. The first test evaluated four commercial products registered for the control of potato blight: chlorothalonil+metalaxyl (Folio Gold ${ }^{\circledR} 742.5 \mathrm{WP}$ ); propamocarb chloridrate (Infinito ${ }^{\circledR} 687.5 \mathrm{CS}$ ), metalaxyl-m+mancozeb (Ridomil Gold ${ }^{\circledR} 68 \mathrm{WP}$ ), cymoxanil + manconzeb (Curzate ${ }^{\circledR}$ MZ $72 \mathrm{WG}$ ), at the recommended doses. The other assays evaluated three doses of Infinito $(0.125 \%, 0.150 \%$ or $0.175 \%)$ and Ridomil. In vivo test was done in the greenhouse, and the experimental unit consisted of one pot, containing one tomato seedling, cultivar Alambra F1. Fungicide was drenched on the seedling soil one day prior to inoculation with 50,000 zoospores per pot. Data of mycelia growth inhibition by fungicide were submitted to analysis of variance and the averages compared by the Tukey test at $5 \%$ significance; efficacy was determined as a function of Ridomil@, the standard fungicide. In the first test, regardless of isolate, Infinito® presented performance similar to Ridomil ${ }^{\circledR}$ with efficacy of $98.5 \%$, while Folio Gold ${ }^{\circledR}$ presented efficacy of $57.3 \%$ and Curzate ${ }^{\circledR}$ had no fungicide effect. Growth of isolate PP3 was smaller in all fungicides. In the second in vitro test, all three doses of Infinito ${ }^{\circledR}$ had efficacy above $82 \%$. The best control was observed on isolates PP3 and PP4. In the third test, in vivo, no significant differences were observed in root matter among the standard fungicide and the doses of Infinito ${ }^{\circledR}$; however, efficacy of Infinito ${ }^{\circledR}$ at $0.175 \%$ was $14 \%$ greater than that obtained with Ridomil ${ }^{\circledR}$. It can be concluded that Infinito ${ }^{\circledR}$ is one more option for the control of tomato wilt.
\end{abstract}

KEYWORDS: Fungicides. Solanum lycopersicum. Phytophthora sp.

\section{INTRODUCTION}

Tomato (Solanum lycopersicum) has wide climate adaptation, and the most important factors for yield are temperature, soil and air moisture, and photoperiod (ALVARENGA, 2004). Besides the direct effect on plant metabolism, these factors also affect the development of sanitary problems, together with other soil characteristics, plant management, irrigation method, cultivar, plant nutritional state, pathogen population and antagonist microbiota present in the soil (LOPES; ÁVILA, 2005; FILGUEIRA, 2008). There are approximately 200 diseases and physiological disturbances reported in this crop. Although no more than five of these may occur simultaneously, damage and losses may render the crop non viable in certain seasons of the year, when control becomes ineffective, or production costs increase in such a manner that there is no economic return from it (LOPES; ÁVILA, 2005). Control of these diseases does not consist in exterminating the pathogen after it becomes visible, but, it is permanent integrated control measures, preferably avoiding the entrance of the pathogen in the area or its establishment in it. Large scale tomato production is heavily dependent on fungicide use; however, its use depends on approval by the Ministério da Agricultura Pecuária e Abastecimento (MAPA) (LOPES; ÁVILA, 2005). Late blight is the most important tomato disease in Brazil, especially in the South and Southeast, where it is more aggressive; however, epidemics have also been reported in the Northeast, when cold and moist nights might occur occasionally (LOPES; ÁVILA, 2005). This disease is caused by Phytophthora infestans, and can completely destroy tomato and potato fields in a very short period of time when environment conditions are adequate (REIS et al., 2001; KUROZAWA; PAVAN, 2005; LOPES; ÁVILA, 2005).

The species $P$. capsici, causal agent of Phytophthora wilt, may present symptoms similar to those of $P$. infestans in tomato plants (ERWIN; RIBEIRO, 1996; QUESADA-OCAMPO; 
HAUSBECK, 2010). Such symptom similarity demands the identification of each species in order to adopt more adequate management strategies, especially when considering that there is only one fungicide registered in MAPA for $P$. capsici in tomatoes, in contrast to $P$. infestans, which has 114 registered products. Diseases caused by $P$. capsici are intimately related to irrigation systems. Sprinkler systems favor greater development of leaf lesions, while furrow irrigation favors root rots. Moreover, excess moisture and temperatures between 18 and $30^{\circ} \mathrm{C}$ favor speedy disease progress (ERWIN; RIBEIRO, 1996). Ideal temperature range for disease development is 25 to $30^{\circ} \mathrm{C}$, which is very common in tomato producing areas in Brazil (KUROZAWA; PAVAN, 2005; HAUSBECK; LAMOUR, 2004), and this range is above that ideal for P. infestans.

This study analyzed the in vitro effect of fungicides on the control of Phytophthora isolates pathogenic to tomatoes, and in vivo for the control of Phytophthora wilt in tomatoes, in greenhouse conditions.

\section{MATERIAL AND METHODS}

\section{Isolates and inoculum production}

The three Phytophthora sp. isolates used belong to the collection of the Laboratório de Virologia e Fitopatologia, at the Universidade Federal de Uberlândia, and were characterized by Ramos (2010) as capable of growing at $35^{\circ} \mathrm{C}$ and pathogenic to Bell pepper. Preliminary studies also confirmed their pathogenicity to tomatoes. The isolates were maintained routinely in CMA (cornmeal agar).

Zoospores were induced by transferring the isolates to clarified V8 broth, in Petri plates. Three 5-mm diameter mycelial plugs, removed from the border of CMA grown colonies, were transferred to the V8 plates and incubated in the dark, at $25^{\circ} \mathrm{C}$. One week later, the growth medium (V8) was drained, and the mycelial mat was rinsed in sterile distilled water, and replaced with $20 \mathrm{ml}$ of sterile distilled water. Subsequently, the mycelial mats were incubated on the laboratory bench, under continuous lighting for four days, to induce sporangia formation. Finally, the plates were kept at $4^{\circ} \mathrm{C}$ for $30 \mathrm{~min}$, inducing the cleavage of zoospores, which were released after returning the plates to the bench top. The zoospore suspension of the plates was poured into beakers, one for each isolate, and $10 \mu \mathrm{L}$ aliquots were used to quantify the zoospores under a light microscope, and the volume required to obtain 50,000 zoospores per plant determined.

\section{In vitro experiments}

Two experiments were done in Petri plates to determine isolate sensitivity to fungicides and the efficacy of four main recommended commercial fungicides for the control of potato late blight, caused by $P$. infestans, because, although they are registered for use in tomatoes, they are not for the putative pathogen $P$. capsici (Table 1).

The first experiment was a $4 \times 3$ factorial, with four fungicides and three isolates, with five replications, done in a growth chamber, at $25^{\circ} \mathrm{C}$. The experimental unit consisted of a 5-mm diameter mycelial plug placed $30 \mathrm{~mm}$ away from a similar size filter paper soaked in the fungicide (Table 2), over CMA. Negative control (distilled water) was used as an indicator for the end of the experiment (mycelium touching the paper disk) and recording the results. The variable determined was the inhibition halo, i.e., the distance between the border of the mycelial mat and the paper disk.

Inhibition halo values were submitted to the analysis of variance and the averages compared by the Tukey test at 5\% significance. Efficacy was obtained as a function of the positive control (mancozeb+metalaxyl-M).

The second experiment evaluated the performance of three doses of propamocarb +fluopicolide $(0.125 \%, 0.150 \%$ or $0.175 \%)$, on the Phytophthora sp. isolates, in comparison to mancozeb+metalaxyl-M $(0.25 \%)$, as described for the first experiment.

\section{Greenhouse experiment}

The test was done in the greenhouse at the Universidade Federal de Uberlândia (UFU), from August to September 2010, comparing the three doses of propamocarb +fluopicolide $(0.125 \%$, $0.150 \%$ or $0.175 \%$ ) to mancozeb+metalaxyl-M $(0.25 \%)$ for in vivo control of Phytophthora sp. isolates in tomato seedlings. The experimental design was completely randomized, as a $4 \times 3$ factorial (4 fungicides and three isolates) and an additional treatment (non-inoculated control), with five replications. The experimental unit consisted of one tomato seedling (variety Alambra F1).

Fourteen days old seedlings, containing six true leaves, produced in trays, containing substrate (Bioplant), were transplanted to $200-\mathrm{mL}$ plastic cups, containing a mixture of expanded vermiculite, earthworm humus, sand and soil, in the proportion $1: 1: 2: 4$, respectively. Inoculation with 50,000 zoospores per plant was done eight days after transplanting, and $24 \mathrm{~h}$ after drenching the seedlings with $60 \mathrm{~mL}$ of fungicide solution per plant. The cups were placed in trays and filled with tap water 
up to the root collar before inoculation. The zoospore suspension was pipetted to the root collar zone of each plant and, subsequently, the water was slowly drained from the trays, favoring zoospore movement toward the root tips. The control tray was filled with water and drained, similarly to the inoculated ones, but with no zoospores.

Table 1. Characterization of fungicides used for the control of Phytophthora sp.

\begin{tabular}{|c|c|c|c|}
\hline $\begin{array}{c}\text { Commercial } \\
\text { product }\end{array}$ & Active ingredient * & Chemical group* & Mode of action ** \\
\hline \multirow{2}{*}{$\begin{array}{c}\text { Ridomil Gold } \\
\text { MZ } \\
\text { (WP) }\end{array}$} & metalaxyl-M $\quad\left(40 \mathrm{~g} \mathrm{~kg}^{-1}\right)$ & Acylamino acid & Nucleic acid synthesis \\
\hline & mancozeb $\quad\left(640 \mathrm{~g} \mathrm{~kg}^{-1}\right)$ & dithiocarbamate & General interference in cell functions \\
\hline \multirow{2}{*}{ Infinito (SC) } & propamocarb $\left(625 \mathrm{~g} \mathrm{~L}^{-1}\right)$ & carbamate & Lipid synthesis \\
\hline & fluopicolide $^{\dagger}\left(62.5 \mathrm{~g} \mathrm{~L}^{-1}\right)$ & benzamide & Mitosis and cell division inhibition \\
\hline \multirow{2}{*}{ Folio Gold (WP) } & chlorothalonil $\left(675 \mathrm{~g} \mathrm{~kg}^{-1}\right)$ & isoftalonitrile & General interference in cell functions \\
\hline & metalaxyl-M $\left(67.5 \mathrm{~g} \mathrm{~kg}^{-1}\right)$ & Acylamino acid & Nucleic acid synthesis \\
\hline \multirow{2}{*}{$\begin{array}{l}\text { Curzate BR } \\
\text { (WP) }\end{array}$} & cymoxanil $\left(80 \mathrm{~g} \mathrm{~kg}^{-1}\right)$ & acetamide & Nucleic acid synthesis \\
\hline & mancozeb $\left(640 \mathrm{~g} \mathrm{~kg}^{-1}\right)$ & ditiocarbamates & General interference in cell functions \\
\hline
\end{tabular}

Table 2. Commercial doses used to determine fungicide efficacy.

\begin{tabular}{cc}
\hline Fungicide & Dose \\
\hline mancozeb + metalaxyl-M & $0.250 \%$ \\
propamocarb + fluopicolide & $0.130 \%$ \\
chlorothalonil + metalaxyl-M & $0.200 \%$ \\
cymoxanil + mancozeb & $0.200 \%$ \\
\hline
\end{tabular}

The evaluation was done 14 days after inoculation, determining disease incidence and root mass. Diseased root tissue was plated in PARP medium (MITCHELL; KANNWISCHERMITCHELL, 1992) to confirm the presence of the pathogen.

The data were submitted to the analysis of variance and the averages compared by the Tukey test at $5 \%$ probability. Efficacy was determined as a function of negative control (with no fungicide) and of the positive control (mancozeb+ metalaxyl-M, standard fungicide):

$$
E F=(A T / A S) * 100
$$

Where:

EF: Percent efficacy,

AT: Average of inhibition halo $(\mathrm{mm})$, or root matter $(\mathrm{g})$, of the treatment,

AS: Average of inhibition halo $(\mathrm{mm})$, or root matter $(\mathrm{g})$, of the positive control (standard fungicide), or of the negative control (no fungicide).

\section{RESULTS AND DISCUSSION}

No significant interactions were observed between fungicides and isolates in the in vitro experiment. Therefore, regardless of isolate, fungicide performance was similar, while isolate 
sensitivity did not vary as a function of fungicide used. However, differences in control among isolates, and among commercial products were found (Tables 3 and 4). Isolate PP3 was the most sensitive isolate to all fungicides in the test, while isolate PP1 was the least sensitive (Table 3).
The performance

of propamocarb+fluopicolide was similar to mancozeb+metalaxyl-M, with efficacy of $98.5 \%$, while chlorothalonil+metalaxyl-M was intermediate, with $57.3 \%$ and cymoxanil+mancozeb was the lowest, with $11.8 \%$ (Table 4).

Table 3. Sensitivity of three Phytophthora sp. isolates to fungicides. Uberlândia, 2011.

\begin{tabular}{cc}
\hline Isolate & Inhibition halo $(\mathrm{mm})$ \\
\hline PP3 & $7.5 \mathrm{a}$ \\
PP1 & $4.95 \mathrm{~b}$ \\
PP4 & $5.37 \mathrm{~b}$ \\
\hline
\end{tabular}

Averages followed by the same letter, in the column, do not differ by the Tukey test at $5 \%$ probability

Table 4. Inhibition of Phytophthora sp. growth in the presence of four fungicides. Uberlândia, 2011.

\begin{tabular}{cccc}
\hline Fungicide & Dose & Inhibition halo (mm) & Efficacy (\%) \\
\hline mancozeb+metalaxyl-M & $0.250 \%$ & $9.07 \mathrm{a}$ & 100 \\
propamocarb+fluopicolide & $0.13 \%$ & $8.93 \mathrm{a}$ & 98.5 \\
chlorothalonil+metalaxyl-M & $0.200 \%$ & $5.2 \mathrm{~b}$ & 57.3 \\
cymoxanil+mancozeb & $0.20 \%$ & $1.07 \mathrm{c}$ & 11.8 \\
\hline
\end{tabular}

Averages followed by the same letter, in the column, do not differ by the Tukey test at $5 \%$ probability

Töfolli et al. (2003), evaluating mycelial growth of Alternaria solani in increasing concentrations of several active ingredients, observed control directly proportional to doses applied, different from what was observed here. The concentration of metalaxyl present in Ridomil Gold® is $40 \mathrm{~g} \mathrm{~kg}^{-1}$, while in Folio Gold® it is $67.5 \mathrm{~g}$ $\mathrm{kg}^{-1}$; however, inhibition was greater in the former, considered as standard fungicide in this study. A possible explanation could be in the other active ingredient added in the formulation with metalaxyl in each commercial product, mancozeb and chlorothalonil, respectively. Moreover, comparing the fungicides Ridomil Gold ${ }^{\circledR}$ and Curzate $\AA$, with the same concentration of mancozeb, efficacy difference is $88.2 \%$, demonstrating the superiority of metalaxyl over cymoxanil (companion active ingredient present in Curzate $\left.{ }^{\circledR}\right)$, or a synergistic action of mancozeb + metalaxyl, which does not occur with mancozeb + cymoxanil.

The fungicide propamocarb+fluopicolide had efficacy similar to the standard, as also observed by Tafforeau et al. (2006) and Latorse et al. (2007). Such results confirm its potential for use in product rotation with mancozeb+metalaxyl, as good practices demand for integrated disease management, since they have different modes of action, minimizing the possibility of inducing resistance, which is common in plant pathogen populations, due to selection pressure caused by the continuous use of the same active ingredient over time (GRÜNWALD et al., 2006).

Strains resistant to a given fungicide occur due to the genetic variability among individuals of the same species (GRÜNWALD et al., 2006). Fungicide sensitivity was different among the isolates evaluates, and PP3 was the most sensitive to all fungicides tested, while PP1 was the least one. The control difference observed among the four commercial products, despite using the recommended doses for $P$. infestans, could be explained to the different species used, probably $P$. capsici by the temperature growth range (ERWIN; RIBEIRO, 1996), implying in physiological, biochemical and morphological changes that modify sensitivity to a fungicide, while differences among isolates can be explained by intra-specific genetic variations.

Considering the performance of propamocarb+fluopicolide, three increasing doses were compared to mancozeb+metalaxyl. No significant interaction between fungicides and 
isolates were observed; moreover, isolate PP3 still demonstrated the greatest sensitivity both fungicides (Table 5).

Table 5. Sensitivity of three Phytophthora sp. isolates to increasing doses of propamocarb+fluopicolide $\left(\right.$ Infinito $^{\circledR}$ ). Uberlândia, 2011.

\begin{tabular}{cc}
\hline Isolate & Inhibition halo $(\mathrm{mm})$ \\
\hline PP3 & $14.44 \mathrm{a}$ \\
PP4 & $13.79 \mathrm{a}$ \\
PP1 & $12.11 \mathrm{~b}$ \\
\hline
\end{tabular}

Averages followed by the same letter, in the column, do not differ by the Tukey test at $5 \%$ probability

Small differences were observed between this test and the previous one, as shown by the significant differences between propamocarb+fluopicolide doses and mancozeb+metalaxyl. Increasing doses of propamocarb+fluopicolide did not differ significantly. Efficacy, despite lower than that observed in the first test, was above $80 \%$, sustaining the hypothesis that this product can be recommended for the control of Phytophthora sp. isolates (Table 6).

Table 6. Inhibition of three Phytophthora sp. isolates exposed to increasing doses of propamocarb+fluopicolide $\left(\right.$ Infinito $\left.^{\circledR}\right)$. Uberlândia, 2011.

\begin{tabular}{cccc}
\hline Fungicide & Dose (\%) & Inhibition halo (mm) & Efficacy (\%) \\
\hline mancozeb + metalaxyl-M & 0.25 & $15.29 \mathrm{a}$ & 100.00 \\
\hline \multirow{2}{*}{ propamocarb+fluopicolide } & 0.175 & $12.93 \mathrm{~b}$ & 84.57 \\
\cline { 2 - 4 } & 0.150 & $12.92 \mathrm{~b}$ & 84.50 \\
\cline { 2 - 4 } & 0.125 & $12.64 \mathrm{~b}$ & 82.67 \\
\hline
\end{tabular}

Averages followed by the same letter, in the column, do not differ by the Tukey test at 5\% probability

Necrotic lesions on stems and collar, damping off and severe root rot were observed in plants that received no fungicide treatment (Figure
1). In contrast, treated plants had no damping off or collar annealing, and root matter was much greater than in diseased plants.

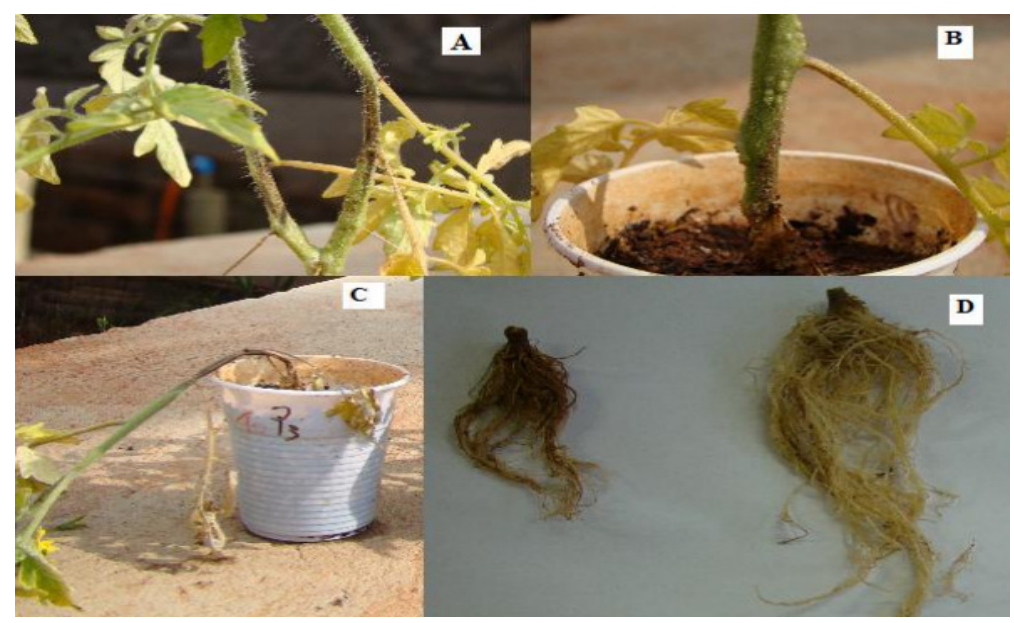

Figure 1. Symptoms caused by Phytophthora sp. in tomato seedlings. (A) Stem necrosis. (B) Collar necrosis and annealing. (C) Damping off. (D) Root rot (untreated control on left, propamocarb+fluopicolide treated on right). Uberlândia, 2011. 
Tomato seedling root matter was compared under different doses of propamocarb+fluopicolide, the standard dose of mancozeb+metalaxyl and a non treated control. No significant interaction was observed between the variables isolate and fungicides, nor between the control and the isolates.
Root matter in the treatments with increasing doses of propamocarb+fluopicolide was similar to that of the standard fungicide, macozeb+metalaxyl-M; however, they were significantly different from the untreated control (Table 7).

Table 7. Tomato seedling root matter inoculated with three Phytophthora sp. isolates after drenching with fungicides. Uberlândia, 2011.

\begin{tabular}{ccccc}
\hline \multirow{2}{*}{ Fungicide } & Dose & $\begin{array}{c}\text { Root matter } \\
(\mathrm{g})\end{array}$ & $\begin{array}{c}\text { Efficacy (standard fungicide) } \\
(\%)\end{array}$ & $\begin{array}{c}\text { Efficacy (untreated } \\
\text { control) }(\%)\end{array}$ \\
\hline mancozeb + metalaxyl-M & $0.25 \%$ & $4.61 \mathrm{a}$ & 100.00 & 238.86 \\
\hline \multirow{3}{*}{ propamocarb+fluopicolide } & $0.175 \%$ & $5.30 \mathrm{a}$ & 114.97 & 231.61 \\
\cline { 2 - 5 } & & & & 96.96 \\
& $0.150 \%$ & $4.47 \mathrm{a}$ & 252.33 \\
\cline { 2 - 5 } & $0.125 \%$ & $4.87 \mathrm{a}$ & 105.64 & 100.00 \\
\hline Untreated control & $0.25 \%$ & $1.93 \mathrm{~b}$ & & - \\
\hline
\end{tabular}

Averages followed by the same letter, in the column, do not differ by the Tukey test at $5 \%$ probability

Efficacy, determined as a function of the standard fungicide, demonstrated for the doses $0.125 \%$ and $0.175 \%$, that propamocarb+fluopicolide was greater than that of the standard fungicide mancozeb+metalaxyl-M at the recommended dose $(0.25 \%$ a.i.), characterizing a phytotonic effect on the seedlings (Figure 2). The comparison with the negative control showed much greater root matter, $174 \%$ more in the treatment with $0.175 \%$ propamocarb+fluopicolide and $138 \%$ in the treatment with mancozeb+metalaxyl-M. Souza et al. (2014), comparing the effect of fungicide application with Trichoderma spp., for the control of late blight in tomatoes, observed increment in fresh matter and fruit yield in treatments with propamocarb+fluopicolide.

Control efficacy observed for the commercial mixtures of propamocarb+fluopicolide and mancozeb+metalaxyl are in agreement with results obtained in the control of $P$. infestans in tomato and potato plants, in studies of Reiter et al. (1995), Rodrigues et al. (2000), Töfolli et al. (2003), Tafforeau et al. (2006), Latorse et al. (2007), Töfolli et al. (2012), and Souza et al. (2014).

The combination of propamocarb+fluopicolide present high residual, protective, curative and anti-sporulating effect due to the chemical characteristics of the molecules
(JOHNSON et al., 2000; SOUZA et al., 2014). Fluopicolide has transblade action, tending to create a protective layer under the leaf surface, acting on the pathogen by interrupting important metabolic pathways for protein synthesis of oomycetes (TAFFOREAU et al., 2006; LATORSE et al., 2007). Propamocarb, in turn, penetrates the plant tissue, moving and acting directly on the development of fungal vegetative and reproductive structures (JOHNSON et al., 2000).

\section{CONCLUSIONS}

The commercial products
mancozeb+metalaxyl and propamocarb+fluopicolide are effective in the control of Phytophthora sp. in vitro. The commercial products chlorothalonil+metalaxyl-M and cymoxanil+mancozeb do not provide adequate control of Phytophthora sp. mycelial growth in these conditions. The commercial product propamocarb+fluopicolide, at the doses $0.125 \%$, $0.150 \%$ and $0.175 \%$ presents efficacy above $80 \%$ in in vitro test.

In vivo test of propamocarb+fluopicolide, at the doses $0.125 \%, 0.150 \%$ and $0.175 \%$, controls tomato seedling root rot as effectively as the commercial product mancozeb+metalaxyl-M. 
Propamocarb+fluopicolide, at the doses $0.125 \%$ and $0.175 \%$, has greater efficacy than the standard fungicide, suggesting a phytotonic effect. Therefore, the commercial product propamocarb+fluopicolide can be used for the control of Phytophthora sp. isolates, and is an option for active ingredient rotation with mancozeb+metalaxyl-M, since both of them are effective on the control of this pathogen and present different modes of action.

\section{ACKNOWLEDGEMENTS}

To Agricultural Engineer Wilson Ferreira (Bayer CropSciences) for providing the fungicides and insights on the tests; to Prof. Dr. Jonas Jäger Fernandes for the cooperation on all steps of the research and critique of the manuscript. The first author is indebt to UFU/CNPq for the scholarship.

RESUMO: O método mais efetivo no manejo das doenças fúngicas que afetam o tomateiro e reduzem a produtividade significativamente é o uso de fungicidas. Este trabalho avaliou a eficiência do controle químico sobre três isolados de Phytophthora sp. patogênicos ao tomateiro. O efeito de fungicidas no crescimento micelial de Phytophthora sp. e na murcha de tomateiro foi avaliado in vitro e in vivo, respectivamente. Foram realizados dois testes em placa de Petri e um teste em mudas, em delineamento experimental inteiramente casualizado (DIC), como fatorial $4 \times 3$, com 5 repetições. Os testes in vitro ocorreram em câmara de crescimento, a $25^{\circ} \mathrm{C}$. A parcela experimental correspondeu a um disco de micélio fúngico disposto a $30 \mathrm{~mm}$ de um disco de papel embebido com solução de fungicida, ambos com $5 \mathrm{~mm}$ de diâmetro e dispostos sobre meio sólido a base de milho. O primeiro teste avaliou quatro produtos comerciais indicadas para o controle da mela ou requeima no tomateiro: clorotalonil+metalaxil (Folio Gold® 742,5 PM); propamocarbe (Infinito ${ }^{\circledR}$ 687,5 SC), metalaxil-M+mancozeb (Ridomil Gold ${ }^{\circledR} 68$ PM), cimoxanil + manconzeb (Curzate ${ }^{\circledR}$ MZ 72 WG), nas dosagens recomendadas. Os demais ensaios avaliaram três doses de Infinito $(0,125 \%, 0,150 \%$ e $0,175 \%)$ e Ridomil. O teste in vivo foi realizado em casa de vegetação, sendo a parcela experimental representada por um vaso, contendo uma muda de tomate, variedade Alambra F1. Fez-se "drench" para aplicação do fungicida no dia anterior à inoculação de 50.000 zoósporos por vaso. Dados de inibição do crescimento micelial por fungicidas foram submetidos à análise de variância e as médias comparadas pelo teste de Tukey a $5 \%$ de significância; e a eficácia foi calculada em função do Ridomil®, fungicida padrão. No primeiro ensaio, independentemente do isolado, Infinito® apresentou desempenho semelhante ao Ridomil® com uma eficácia de 98,5\%, enquanto Folio Gold® apresentou eficácia de 57,3\% e Curzate não apresentou efeito fungicida. O crescimento do isolado PP3 foi menor em todos os produtos. No segundo teste in vitro as três doses de Infinito® tiveram eficácia superior a 82\%. O melhor controle foi observado sobre os isolados PP3 e PP4. No terceiro teste, in vivo, não houve diferença significativa na massa de raízes, entre o padrão e as doses de Infinitoß, no entanto, a eficácia de Infinito® a $0,175 \%$ foi $14 \%$ maior que a obtida para o Ridomil®. Conclui-se que Infinito® é mais uma opção para controle da mela em tomateiro

PALAVRAS-CHAVE: Fungicidas. Solanum lycopersicum. Phytophthora sp.

\section{REFERENCES}

AGRIOS, G. N. Plant Pathology. $4^{\text {th }}$ ed. San Diego, Academic Press, 1997. 635 p.

AGROFIT. Available in: http://extranet.agricultura.gov.br/agrofit_cons/principal_agrofit_cons. Access on 24/October/2011.

ALVARENGA, M. A. R. Origem botânica e descrição da planta. In: Tomate: Produção em campo, em casa de vegetação e em hidroponia. Lavras: Editora UFLA, 2004. p. 15-24.

ERWIN, D. C.; RIBEIRO, O. K. Phytophthora Diseases Worldwide. St. Paul: The American Phytopathological Society, 1996. 562 p.

FILGUEIRA, F. A. R. Novo manual de olericultura: agrotecnologia moderna na produção e comercialização de hortaliças. 3. ed. Viçosa: UFV, 2008. 421 p.

GRÜNWALD, N. J.; STURBAUM, A. K.; MONTES, G. R.; SERRANO, E. G.; LOZOYA-SALDANA, H.; FRY, W. E. Selection for fungicide resistance within a growing season in field populations of Phytophthora infestans at the center of origin. Phytopathology, Saint Paul, v. 96, p. 1397-1403. 2006. http://dx.doi.org/10.1094/PHYTO-96-1397 
HAUSBECK, M. K.; LAMOUR, K. H. Phytophthora capsici on vegetable crops: research progress and management challenges. Plant Disease, Saint Paul, v. 80, n. 12, p. 1292 - 1303. Dec., 2004.

http://dx.doi.org/10.1094/PDIS.2004.88.12.1292

IBGE. Levantamento Sistemático da Produção Agrícola (LSPA). Available in:

http://www.ibge.gov.br/home/estatistica/indicadores/agropecuaria/lspa/lspa_201108.pdf. Access on 24/October/2011.

JOHNSON, D. A.; CUMMINGS, T. F.; GEARY, B. Postinfection activity of selected late blight fungicides. Plant Disease, Saint Paul, v. 84 n. 10, p. 1116 - 1120, 2000. http://dx.doi.org/10.1094/PDIS.2000.84.10.1116

KUROZAWA, C.; PAVAN, M. A. Doenças das solanáceas. In: KIMATI, H.; AMORIN, L.; REZENDE, J. A. M.; BERGAMIN FILHO, A; CAMARGO, L. E. A. (ed.). Manual de Fitopatologia: Doenças das Plantas Cultivadas, v. 2, $4^{a}$ ed., Piracicaba: Editora Agronômica Ceres, 2005. p. 589-596.

LATORSE, M. P.; JARRY, F.; MERCIER, V.; VELOSO, S. Tuber blight control: effect of foliar applied fungicides such as Infinito on viability of sporangia of Phytophthora infestans. PPO-Special Report, Wageningen, v. 12, p. 37-47, 2007.

LOPES, C. A.; ÁVILA, A. C. Doenças do tomateiro. Brasília: Embrapa Hortaliças. 2005. 151 p.

MAKISHIMA, N.; MELO, W. F. O rei das hortaliças. Cultivar HF, Pelotas, n. 29, p. 28-32. dez., 2004- jan. 2005.

MITCHELL, D. J.; KANNWISCHER-MITCHELL, M. E. Phytophthora. In. SINGLETON, L. L.; MIHAIL, J. D.; RUSH, C. M. (Ed.) Methods for research on soilborne phytopathogenic fungi. St. Paul: American Phythopathological Society, 1992. p. 31-38.

QUESADA-OCAMPO, L. M.; HAUSBECK, M. K. Resistance in tomato and wild relatives to crown and root rot caused by Phytophthora capsici. Phytopathology, Saint Paul, v. 100, p. 619-627. 2010.

http://dx.doi.org/10.1094/PHYTO-100-6-0619

RAMOS, F. C. Isolamento e patogenicidade de isolados de Phytophthora sp. em pimentão (Capsicum annuum). 2010. 22 f. Monograph (Graduation in Agronomy) - Universidade Federal de Uberlândia, Uberlândia, 2010.

REIS, E. M.; MEDEIROS, C. A.; BRESOLIN, A. C. R.; CASA, R. T. Requeima: Ameaça à Batata e ao Tomate. Cultivar HF, v. 6, fev.-mar., 2001. Available in http://www.grupocultivar.com.br/site/content/artigos/artigos.php?id=152. Access 24/October/2011.

REITER, B.; WENZ, M.; BUSCCHHAUS, H.; BUCHENAUER, H. Effect of propamocarb hydrochloride on Phytophthora infestans in vitro and in potato and tomato plant. Gesunde Pflanzen, Berlin, v. 47, p. 43-50. 1995.

RISTAINO, J. B. Intraespecific variations among isolates of Phytophthora capsici from pepper and cucurbit fields in North Carolina. Phytopathology, Saint Paul, v. 80, n. 11, p. 1253 - 1259, 1990. http://dx.doi.org/10.1094/Phyto-80-1253

RISTAINO, J. B.; JOHNSTON, S. A. Ecologically based approaches to management of Phytophthora blight on bell pepper. Plant Disease, Saint Paul, v. 83, n. 12, p. 1080 - 1089. 1999.

http://dx.doi.org/10.1094/PDIS.1999.83.12.1080

RODRIGUES, C.; RIBEIRO, L. G.; LOPES, J. C.; FREITAS, F. S.; AZEVEDO, L. A. S. Eficiência do metalaxyl no controle da requeima do tomateiro. Horticultura Brasileira, Brasília, v. 8, p. 65-67. 2000. http://dx.doi.org/10.1590/S0102-05362000000100015 
RODRIGUES, M. A. T. Classificação de fungicidas de acordo com o mecanismo de ação proposto pelo FRAC. 2006. 291 f. Dissertation (Master's degree in Agriculture - Plant Protection). UNESP. Botucatu. 2006.

SOUZA, J. R.; REBOUÇAS, T. N. H.; LUZ, J. M. Q.; AMARAL, C. L. F.; FIGUEIREDO, R. M.;

SANTANA, C. M. P. Potencialidade de fungicidas biológicos no controle de requeima do tomateiro.

Horticultura Brasileira, Brasília, v. 32, p. 115-119. 2014. http://dx.doi.org/10.1590/S0102-

05362014000100020

TAFFOREAU, S.; BARDSLEY, E.; LATORSE, M. P.; FABRÈGES, C.; SCHIRRINGS, A.; WEGMANN, T. Infinito: Profile of a novel potato late blight fungicide. Summary of three years of development trials in Europe. PPO-Special Report, Wageningen, v. 11, p. 77-88, 2006.

TÖFOLLI, J. G.; DOMINGUES, R. J; KWROZAWA, C. Ação "in vitro" de fungicidas no crescimento micelial e germinação de conídios de Alternaria solani, agente causal da pinta preta do tomateiro. Arquivos do Instituto Biológico, São Paulo, v. 70, n. 3, p. 337-345, jul./set., 2003.

TÖFOLLI, J. G.; MELO, P. C. T.; GARCIA, J. R. O. Ação protetora, residual, curativa e anti esporulante de fungicidas no controle da requeima e da pinta preta da batata em condições controladas. Arquivos do Instituto Biológico, São Paulo, v. 79, p. 209-221. 2012. http://dx.doi.org/10.1590/S1808-16572012000200009

TOQUIN, V.; BARJA, F.; SIRVEN, C.; GAMET, S.; LATORSE, M.-P.; ZUNDEL, J.L., SCHMITT, F.;

BEFFA, R. A new mode of action for fluopicolide: modification of the cellular localization of a spectrin-like protein. Pflanzenshutz - Nachrichten Bayer, Leverkusen, v. 59, 2006, 2-3, p. 171 - 184. 